\title{
Molecular functions of SIRP $\alpha$ and its role in cancer (Review)
}

\author{
SHINICHIRO TAKAHASHI \\ Division of Laboratory Medicine, Faculty of Medicine, Tohoku Medical and \\ Pharmaceutical University, Miyagino-ku, Sendai 983-8536, Japan
}

Received February 13, 2018; Accepted May 21, 2018

DOI: $10.3892 /$ br.2018.1102

\begin{abstract}
Signal regulatory protein $\alpha(\mathrm{SIRP} \alpha)$, also known as cluster of differentiation (CD)172a or Src homology 2 domain-containing phosphatase substrate-1, is a cell surface receptor expressed on myeloid and hematopoietic stem cells and neurons. Accumulating data suggests an important role of SIRP $\alpha$ in cell signaling as a negative regulator of the phosphatidylinositol 3-kinase signaling and mitogen-activated protein kinase pathways. In various cancers, including prostate, breast and liver, as well as astrocytoma and myeloid malignancies, downregulation of SIRP $\alpha$ is frequently observed, resulting in activation of these downstream signaling pathways. In turn, cell proliferation, transformation, migration and invasion may occur. Recently, it has been reported that blocking CD47, an anti-phagocytic signal expressed on tumor cells and an SIRP $\alpha$ ligand, may serve as a promising therapeutic approach, particular for the treatment of acute myeloid leukemia. In the present review, the current findings on SIRP $\alpha$ are summarized, with particular focus on its role in cancer.
\end{abstract}

\section{Contents}

1. Introduction

2. SIRP $\alpha$ function

3. CD47, an anticancer therapeutic target

4. SIRP $\alpha$ in cancer

5. Conclusion

Correspondence to: Professor Shinichiro Takahashi, Division of Laboratory Medicine, Faculty of Medicine, Tohoku Medical and Pharmaceutical University, 1-15-1 Fukumuro, Miyagino-ku, Sendai 983-8536, Japan

E-mail: shintakahashi@tohoku-mpu.ac.jp

Key words: signal regulatory protein $\alpha$, cancer, myeloid malignancies, cluster of differentiation 47 , acute myeloid leukemia

\section{Introduction}

The signal regulatory protein (SIRP) family consists of an inhibitory receptor, SIRP $\alpha$, an activating receptor, SIRP $\beta$ [also known as cluster of differentiation (CD)172b] and a non-signaling receptor, SIRP $\gamma$ (also known as CD172g) $(1,2)$. SIRPa, also known as CD172a or Src homology 2 (SH2) domain-containing phosphatase substrate-1, is a cell surface receptor expressed predominantly in monocytes, granulocytes, dendritic cells and hematopoietic stem cells (3). SIRP $\alpha$, SIRP $\beta$ and SIRP $\gamma$ have distinct expression patterns, with SIRP $\alpha$ expressed in myeloid cells and neurons, SIRP $\beta$ expressed in macrophages and neutrophils, and SIRP $\gamma$ expressed in lymphocytes and natural killer cells (1). SIRP $\alpha$ has two distinct isoforms, SIRP $\alpha 1$ and SIRP $\alpha 2$. SIRP $\alpha 2$, also termed brain immunoglobulin-like molecule with tyrosine-based activation motifs (4), shares structural similarity with SIRP $\alpha 1$. In fact, SIRP $\alpha 1$ and SIRP $\alpha 2$ are structurally identical except for their $\mathrm{N}$-terminal immunoglobulin (Ig)-like domain (IgV), which is critical for binding to CD47. As SIRP $\alpha$ is established as an immunoreceptor harboring an $\operatorname{IgV}$ domain $(5,6)$, it is generally considered as SIRP $\alpha 1$ unless noted otherwise. SIRP $\alpha$ is the most characterized member of the human SIRP family. The present review summarizes recent progress in the analysis of SIRP $\alpha$ function and the role of this molecule in cancer, introducing data from recent analyses by our group in leukemia cell lines.

\section{SIRPa function}

The functions of SIRP $\alpha 1$ and SIRP $\alpha 2$ are fundamentally similar; both exert a marked suppressive effect on the anchorage-independent growth of cells (7). In addition, the binding of SIRP $\alpha$ to its ligand, CD47, transduces a downregulation signal that inhibits cell phagocytosis (2). Overexpression of SIRP $\alpha$ may lead to reduced responsiveness to tyrosine kinase ligands, including epidermal growth factor (EGF), platelet-derived growth factor and insulin (3). Several reports have demonstrated that downregulation of $\operatorname{SIRP} \alpha$ resulted in activation of downstream pathways (8-11). However, this remains controversial as it has also been reported that when SIRP $\alpha$ was transfected into either murine NIH3T3 or rat Rat1 fibroblasts expressing insulin receptor, it augmented insulin-stimulated phosphorylation of mitogen-activated protein kinase (MAPK) (12). Thus, the role of SIRP $\alpha$ may 
Table I. Expression and functions of SIRP $\alpha$ in various cancers.

SIRP $\alpha$

\begin{tabular}{|c|c|c|c|}
\hline Tissue & Expression & Functions & Refs. \\
\hline Prostate cancer & $\begin{array}{l}\text { Downregulated in prostate } \\
\text { cancer tissues and cell lines }\end{array}$ & $\begin{array}{l}\text { SIRP } \alpha \text { overexpression resulted in a decrease in the number of } \\
\text { live prostate cancer cells, while SIRP } \alpha \text { silencing increased } \\
\text { prostate cancer proliferation. }\end{array}$ & (30) \\
\hline Brain cancer & $\begin{array}{l}\text { Expressed in } 8 \text { of } 9 \\
\text { astrocytoma cell lines and } \\
7 \text { of } 10 \text { primary brain tumor } \\
\text { biopsies }\end{array}$ & $\begin{array}{l}\text { Reduced cell transformation, migration and invasion, } \\
\text { and enhanced apoptosis following DNA damage. }\end{array}$ & $(33,34)$ \\
\hline Breast cancer & $\begin{array}{l}\text { Downregulated in breast } \\
\text { cancer tissues }\end{array}$ & $\begin{array}{l}\text { Overexpression of Src homology } 2 \text { domain-containing } \\
\text { phosphatase substrate-1 (SIRP } \alpha) \text { resulted in suppression of } \\
\text { anchorage-independent cell growth in soft agar, } \\
\text { and in peritoneal dissemination in nude mice. Forced expression } \\
\text { of SIRP } \alpha \text { specifically suppressed anchorage-independent growth } \\
\text { of the breast cancer cell lines, Hs } 578 \mathrm{~T} \text { and MCF7. }\end{array}$ & $(7,35)$ \\
\hline Liver cancer & $\begin{array}{l}\text { Lower expression in } \\
\text { hepatocellular carcinoma } \\
\text { tissues than in matched } \\
\text { normal tissues }\end{array}$ & $\begin{array}{l}\text { Overexpression of SIRP } \alpha 1 \text { resulted in a decrease in } \\
\text { hepatocellular carcinoma cell number. } \\
\text { SIRP } \alpha 1 \text {-transfected Huh7 cells exhibited reduced cell migration } \\
\text { and invasion in a manner that was dependent on SIRP } \alpha 1 / \text { SHP-2 } \\
\text { complex formation. }\end{array}$ & $(36,37)$ \\
\hline $\begin{array}{l}\text { Myeloid } \\
\text { malignancies }\end{array}$ & $\begin{array}{l}\text { Significantly suppressed in } \\
\text { the majority of myeloid } \\
\text { malignancies }\end{array}$ & 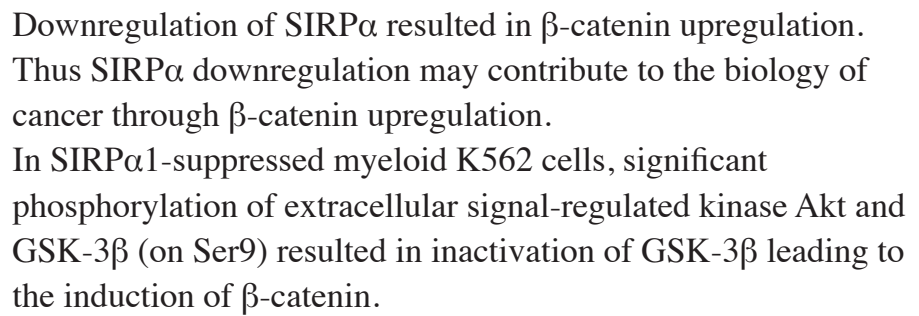 & $(8,38)$ \\
\hline
\end{tabular}

SIRP, signal regulatory protein; GSK, glycogen synthesis kinase.

depend on its expression level or on the cell type in which it is expressed (12).

\section{CD47, an anticancer therapeutic target}

As there are previous reviews on the relationships between CD47 and SIRP $\alpha(2,13)$, how CD47 modulates the function of SIRP $\alpha$ is only briefly discussed here. CD47 is a membrane protein expressed in nearly all cell types (2). The Ig domain of CD47 and the N-terminal Ig domain of SIRP $\alpha$ may bind directly, and this binding is reportedly sufficient for mediating transcellular bidirectional signaling via the respective cytoplasmic regions (14). In particular, the binding of SIRP $\alpha$ to CD47 promotes tyrosine phosphorylation of the cytoplasmic region of SIRP $\alpha$ (15). The protein tyrosine phosphatase, SHP-2 (also known as tyrosine-protein phosphatase non-receptor type 11), may then bind to the cytoplasmic region of SIRP $\alpha$ (12) to mediate the functions of SIRP $\alpha$ by dephosphorylating its substrates. In this regard, SIRP $\alpha$ functions as a negative signaling regulator (12).

CD47, an SIRPa ligand, has been described as an important anti-phagocytic signal expressed on tumor cells $(16,17)$. Therefore, the blockade of CD47 is attracting increasing attention as a potential effective therapeutic approach against cancer (18). Expectedly, CD47 is constitutively upregulated in human myeloid leukemia, and overexpression of CD47 in a myeloid leukemia line has been identified to increase its pathogenicity by enabling it to evade phagocytosis (16). Therefore, inhibiting the CD47-SIRP $\alpha$ axis between tumor and immune cells has become a focus of research (19-23). In addition to the SIRP $\alpha-C D 47$ interaction, SIRP $\gamma$ has been shown to bind CD47, but with lower affinity than that of $\operatorname{SIRP} \alpha$, whereas no detectable binding was observed between CD47 and $\operatorname{SIRP} \beta(1,24)$.

Majeti et al (25), demonstrated that CD47 was expressed at higher levels on acute myeloid leukemia (AML) stem cells than on their normal counterparts. They also revealed that increased CD47 expression predicted worse overall survival in adult AML patients, and that monoclonal antibodies directed against CD47 enabled phagocytosis of AML leukemia stem cells and inhibited their engraftment in vivo (25). Recently, Chen et al (20) reported that macrophages were notably more efficient at phagocytosis of hematopoietic tumor cells compared with non-hematopoietic tumor cells in response to SIRP $\alpha$-CD47 blockade (20). They also revealed that 
SIRP $\alpha-C D 47$ blockade was strictly dependent on signaling lymphocytic activation molecule 7 .

In solid tumors, a moderate increase in CD47 expression has been detected compared with normal tissues, and CD47 transcript expression correlated with adverse prognosis (26). However, inhibition of CD47 function led to tumor cell phagocytosis and elimination (27). Mice harboring leiomyosarcoma, a smooth muscle tumor, have reportedly exhibited significantly reduced primary tumor size following treatment with anti-CD47 antibodies (27). In pancreatic neuroendocrine tumors (28) and small lung cell cancer (29), blocking CD47 signaling inhibited xenograft tumor growth. Although these studies were at the preclinical investigation stage, clinical trials of anti-CD47 antibodies are underway in solid and hematological malignancies (23).

\section{SIRP $\alpha$ in cancer}

Although SIRP $\alpha$ is widely expressed in numerous tissues, SIRP $\alpha$ downregulation has been reported in various cancers (Table I). In general, SIRP $\alpha$ downregulation may result in the activation of downstream signaling pathways that ultimately leads to the augmentation of cancer cell growth. For instance, downregulation of SIRP $\alpha$ expression has been reported in prostate cancer tissues and cell lines; and SIRP $\alpha$ overexpression resulted in a reduction in the number of live prostate cancer cells, whereas SIRP $\alpha$ silencing increased prostate cancer cell proliferation (30).

SHP-2, a ubiquitously expressed SH2 domain-containing tyrosine phosphatase, has been implicated in a variety of signal transduction pathways induced by cytokines, hormones and growth factors including $\operatorname{EGF}(31,32)$. It has been demonstrated that SIRP $\alpha$ receptor associates with SHP-2 to negatively regulate EGF receptor-mediated phosphatidylinositol 3-kinase (PI3K) signaling, resulting in reduced cell transformation, migration and invasion, and enhanced apoptosis following DNA damage in human glioblastoma cells (33). Transfection of SIRP $\alpha$ into the glioblastoma cell line, U87MG, has also been reported to inhibit cell migration and invasion on fibronectin (33). Additionally, it was revealed that SIRP $\alpha$ was expressed in 8 out of 9 astrocytoma cell lines and 7 out of 10 primary brain tumor biopsies (34).

Oshima et al (35), demonstrated that SIRP $\alpha$ was downregulated in breast cancer tissues compared with in matched normal tissues. In v-Src-transformed BALB/c3T3 cells, overexpression of SIRP $\alpha$ resulted in suppression of anchorage-independent cell growth in soft agar, as well as peritoneal dissemination in nude mice (35). Yamasaki et al (7), have also demonstrated that forced expression of SIRP $\alpha 1$ specifically suppressed anchorage-independent growth of the breast cancer cell lines, Hs578T and MCF7.

In addition, SIRP $\alpha 1$ downregulation has been identified in hepatocellular carcinoma tissues and cells, and its overexpression in these cells resulted in a decrease in cellular growth $(36,37)$. Furthermore, the treatment of SIRP $\alpha 1$-transfected Huh7 cells with EGF or hepatocyte growth factor induced tyrosine phosphorylation of SIRP $\alpha 1$ and its association with SHP-2, which was accompanied with reduced extracellular signal-regulated kinase (ERK) 1 phosphorylation (36,37). These SIRP $\alpha 1$-transfected Huh7 cells also exhibited reduced cell migration and invasion.
SIRP $\alpha$ expression has also been reported as significantly suppressed in the majority of myeloid malignancies (38). Notably, there was a lack of SIRP $\alpha 1$ expression in 4 out of 4 chronic myeloid leukemia patients and in 26 out of 59 AML patients analyzed, while there was significantly upregulated expression in normal myelomonocytic cells and in bone marrow hematopoietic stem/progenitor cells (38). Therefore, the suppressed expression is considered to serve a role in the pathogenesis of these cancers through aberrant signaling. Our group has previously reported that the expression of SIRP $\alpha 1$ correlated with the expression of myeloid transcription factor PU.1 in PU.1 transgenic K562 cells (39). As downregulation of PU.1 induces AML development $(40,41)$, suppression of SIRP $\alpha 1$ expression induced by PU.1 downregulation may serve a role in the pathogenesis of AML. Additionally, our group has revealed that SIRP $\alpha 1$ downregulation resulted in $\beta$-catenin upregulation (8). Furthermore, it was identified that in SIRP $\alpha 1$-suppressed myeloid K562 cells, there was significant phosphorylation of ERK, Akt and glycogen synthesis kinase (GSK)-3 $\beta$ (on Ser9); these phosphorylations may have been responsible for inactivation of GSK-3 $\beta$ and thus the induction of $\beta$-catenin (8). As the induction of $\beta$-catenin is a hallmark of cancer (42), it is possible that SIRP $\alpha 1$ downregulation contributes to the biology of cancer through $\beta$-catenin upregulation. Our group has also observed that SIRP $\alpha 1$ downregulation leads to aberrant cell survival of serum-starved SIRP $\alpha$-knockdown cells (unpublished observations). The Ras-ERK-MAPK pathway $(43,44)$ and PI3K/Akt signaling (45) are frequently activated in AML patient myeloblasts, contributing to proliferation, survival and drug resistance of these cells. Therefore, SIRP $\alpha 1$ downregulation may contribute to constitutive activation of these signaling pathways, ultimately resulting in the aberrant proliferation and survival of AML myeloblasts.

\section{Conclusion}

Increasing data suggests a role of SIRP $\alpha$ in immunity and various cancers. SIRP $\alpha$ downregulation may serve, at least in part, a role in the abnormal cell growth, invasion and survival of cancers through aberrant intracellular signaling. In addition, blocking CD47 ligand may be a promising therapeutic strategy, particularly against hematological malignancies. Further analysis of the SIRP $\alpha-C D 47$ axis may provide novel insight into cancer biology and aid the development of molecular-targeted therapies.

\section{Acknowledgements}

Not applicable.

\section{Funding}

The present work was supported in part by Grants-in-Aid for Scientific Research (grant nos. 26460685 and 17K09019) from the Ministry of Education, Science and Culture, Japan.

\section{Availability of data and materials}

Data sharing is not applicable to this article, as no datasets were generated or analyzed during the current review. 


\section{Authors' contribution}

ST performed all aspects of the literature review and wrote the manuscript to be published.

\section{Ethics approval and consent to participate}

Not applicable.

\section{Consent for publication}

Not applicable.

\section{Competing interests}

The author declares no competing interests.

\section{References}

1. Barclay AN and Brown MH: The SIRP family of receptors and immune regulation. Nat Rev Immunol 6: 457-464, 2006.

2. Barclay AN and Van den Berg TK: The interaction between signal regulatory protein alpha (SIRP $\alpha)$ and CD47: Structure function, and therapeutic target. Annu Rev Immunol 32: 25-50, 2014.

3. Kharitonenkov A, Chen Z, Sures I, Wang H, Schilling J and Ullrich A: A family of proteins that inhibit signalling through tyrosine kinase receptors. Nature 386: 181-186, 1997.

4. Sano S, Ohnishi H, Omori A, Hasegawa J and Kubota M: BIT, an immune antigen receptor-like molecule in the brain. FEBS Lett 411: 327-334, 1997.

5. van Beek EM, Cochrane F, Barclay AN and van den Berg TK: Signal regulatory proteins in the immune system. J Immunol 175: 7781-7787, 2005

6. Liu Y, Tong Q, Zhou Y, Lee HW, Yang JJ, Bühring HJ, Chen YT, Ha B, Chen CX, Yang Y, et al: Functional elements on SIRPalpha IgV domain mediate cell surface binding to CD47. J Mol Biol 365: 680-693, 2007.

7. Yamasaki Y, Ito S, Tsunoda N, Kokuryo T, Hara K, Senga T, Kannagi R, Yamamoto T, Oda K, Nagino M, et al: SIRPalpha1 and SIRPalpha2: Their role as tumor suppressors in breast carcinoma cells. Biochem Biophys Res Commun 361: 7-13, 2007.

8. Maekawa T, Imoto A, Satoh T, Okazaki T and Takahashi S Induction of $\beta$-catenin by the suppression of signal regulatory protein $\alpha 1$ in K562 cells. Int J Mol Med 27: 865-872, 2011.

9. van Beek EM, de Vries TJ, Mulder L, Schoenmaker T, Hoeben KA, Matozaki T, Langenbach GE, Kraal G, Everts V and van den Berg TK: Inhibitory regulation of osteoclast bone resorption by signal regulatory protein alpha. FASEB J 23: 4081-4090, 2009.

10. Liu SQ, Alkema PK, Tieché C, Tefft BJ, Liu DZ, Li YC, Sumpio BE, Caprini JA and Paniagua M: Negative regulation of monocyte adhesion to arterial elastic laminae by signal regulatory protein alpha and Src homology 2 domain-containing protein-tyrosine phosphatase-1. J Biol Chem 280: 39294-39301, 2005.

11. Stofega MR, Argetsinger LS, Wang H, Ullrich A and Carter-Su C: Negative regulation of growth hormone receptor/JAK2 signaling by signal regulatory protein alpha. J Biol Chem 275: 28222-28229, 2000 .

12. Takada T, Matozaki T, Takeda H, Fukunaga K, Noguchi T, Fujioka Y, Okazaki I, Tsuda M, Yamao T, Ochi F, et al: Roles of the complex formation of SHPS-1 with SHP-2 in insulin-stimulated mitogen-activated protein kinase activation. J Biol Chem 273 : 9234-9242, 1998.

13. Murata Y,Kotani T, Ohnishi H and Matozaki T: The CD47-SIRPo signalling system: Its physiological roles and therapeutic application. J Biochem 155: 335-344, 2014

14. Oshima K, Ruhul Amin AR, Suzuki A, Hamaguchi M and Matsuda S: SHPS-1, a multifunctional transmembrane glycoprotein. FEBS Lett 519: 1-7, 2002.

15. Okazawa H, Motegi S, Ohyama N, Ohnishi H, Tomizawa T, Kaneko Y, Oldenborg PA, Ishikawa $\mathrm{O}$ and Matozaki T: Negative regulation of phagocytosis in macrophages by the CD47-SHPS-1 system. J Immunol 174: 2004-2011, 2005
16. Jaiswal S, Jamieson CH, Pang WW, Park CY, Chao MP, Majeti R, Traver D, van Rooijen N and Weissman IL: CD47 is upregulated on circulating hematopoietic stem cells and leukemia cells to avoid phagocytosis. Cell 138: 271-285, 2009.

17. McCracken MN, Cha AC and Weissman IL: Molecular Pathways: Activating T cells after cancer cell phagocytosis from blockade of CD47 'don't eat me' signals. Clin Cancer Res 21: 3597-3601, 2015.

18. Chao MP, Weissman IL and Majeti R: The CD47-SIRP $\alpha$ pathway in cancer immune evasion and potential therapeutic implications. Curr Opin Immunol 24: 225-232, 2012.

19. Liu J, Wang L, Zhao F, Tseng S, Narayanan C, Shura L, Willingham S, Howard M, Prohaska S, Volkmer J, et al: Pre-clinical development of a humanized anti-CD47 antibody with anti-cancer therapeutic potential. PLoS One 10: e0137345, 2015.

20. Chen J, Zhong MC, Guo H, Davidson D, Mishel S, Lu Y, Rhee I, Pérez-Quintero LA, Zhang S, Cruz-Munoz ME, et al: SLAMF7 is critical for phagocytosis of haematopoietic tumour cells via Mac-1 integrin. Nature 544: 493-497, 2017

21. Veillette A and Chen J: SIRP $\alpha-C D 47$ immune checkpoint blockade in anticancer therapy. Trends Immunol 39: 173-184, 2018.

22. Ratnikova NM, Lezhnin YN, Frolova EI, Kravchenko JE and Chumakov SP: CD47 receptor as a primary target for cancer therapy. Mol Biol (Mosk) 51: 251-261, 2017 (In Russian).

23. Weiskopf K: Cancer immunotherapy targeting the CD47/SIRPo axis. Eur J Cancer 76: 100-109, 2017.

24. Brooke G, Holbrook JD, Brown MH and Barclay AN: Human lymphocytes interact directly with CD47 through a novel member of the signal regulatory protein (SIRP) family. J Immunol 173 2562-2570, 2004.

25. Majeti R, Chao MP, Alizadeh AA, Pang WW, Jaiswal S, Gibbs KD Jr, van Rooijen N and Weissman IL: CD47 is an adverse prognostic factor and therapeutic antibody target on human acute myeloid leukemia stem cells. Cell 138: 286-299, 2009.

26. Willingham SB, Volkmer JP, Gentles AJ, Sahoo D, Dalerba P, Mitra SS, Wang J, Contreras-Trujillo H, Martin R, Cohen JD, et al: The CD47-signal regulatory protein alpha (SIRPa) interaction is a therapeutic target for human solid tumors. Proc Natl Acad Sci USA 109: 6662-6667, 2012.

27. Edris B, Weiskopf K, Volkmer AK, Volkmer JP, Willingham SB, Contreras-Trujillo H, Liu J, Majeti R, West RB, Fletcher JA, et al: Antibody therapy targeting the CD47 protein is effective in a model of aggressive metastatic leiomyosarcoma. Proc Natl Acad Sci USA 109: 6656-6661, 2012.

28. Krampitz GW, George BM, Willingham SB, Volkmer JP, Weiskopf K, Jahchan N, Newman AM, Sahoo D, Zemek AJ, Yanovsky RL, et al: Identification of tumorigenic cells and therapeutic targets in pancreatic neuroendocrine tumors. Proc Natl Acad Sci USA 113: 4464-4469, 2016.

29. Weiskopf K, Jahchan NS, Schnorr PJ, Cristea S, Ring AM, Maute RL, Volkmer AK, Volkmer JP, Liu J, Lim JS, et al: CD47-blocking immunotherapies stimulate macrophage-mediated destruction of small-cell lung cancer. J Clin Invest 126: 2610-2620, 2016.

30. Yao C, Li G, Cai M, Qian Y, Wang L, Xiao L, Thaiss F and Shi B: Prostate cancer downregulated SIRP- $\alpha$ modulates apoptosis and proliferation through $\mathrm{p} 38-\mathrm{MAPK} / \mathrm{NF}-\varkappa \mathrm{B} / \mathrm{COX}-2$ signaling. Oncol Lett 13: 4995-5001, 2017.

31. Kapoor GS and O'Rourke DM: SIRPalpha1 receptors interfere with the EGFRvIII signalosome to inhibit glioblastoma cell transformation and migration. Oncogene 29: 4130-4144, 2010.

32. Yuan L, Yu WM, Yuan Z, Haudenschild CC and Qu CK: Role of SHP-2 tyrosine phosphatase in the DNA damage-induced cell death response. J Biol Chem 278: 15208-15216, 2003.

33. Wu CJ, Chen Z, Ullrich A, Greene MI and O'Rourke DM: Inhibition of EGFR-mediated phosphoinositide-3-OH kinase (PI3-K) signaling and glioblastoma phenotype by signal-regulatory proteins (SIRPs). Oncogene 19: 3999-4010, 2000.

34. Chen TT, Brown EJ, Huang EJ and Seaman WE: Expression and activation of signal regulatory protein alpha on astrocytomas. Cancer Res 64: 117-127, 2004.

35. Oshima K, Machida K, Ichigotani Y, Nimura Y, Shirafuji N, Hamaguchi M and Matsuda S: SHPS-1: A budding molecule against cancer dissemination. Cancer Res 62: 3929-3933, 2002.

36. Qin JM, Yan HX, Liu SQ, Wan XW, Zeng JZ, Cao HF, Qiu XH, Wu MC and Wang HY: Negatively regulating mechanism of Sirpalpha1 in hepatocellular carcinoma: An experimental study. Hepatobiliary Pancreat Dis Int 5: 246-251, 2006. 
37. Yan HX, Wang HY, Zhang R, Chen L, Li BA, Liu SQ, Cao HF, Qiu XH, Shan YF, Yan ZH, et al: Negative regulation of hepatocellular carcinoma cell growth by signal regulatory protein alpha1. Hepatology 40: 618-628, 2004.

38. Seiffert M, Cant C, Chen Z, Rappold I, Brugger W, Kanz L, Brown EJ, Ullrich A and Bühring HJ: Human signal-regulatory protein is expressed on normal, but not on subsets of leukemic myeloid cells and mediates cellular adhesion involving its counterreceptor CD47. Blood 94: 3633-3643, 1999.

39. Iseki $Y$, Nakahara M, Kubo M, Obata F, Harigae $H$ and Takahashi S: Correlation of PU.1 and signal regulatory protein $\alpha 1$ expression in PU.1 transgenic K562 cells. Int J Mol Med 29: 319-323, 2012.

40. Rosenbauer F, Wagner K, Kutok JL, Iwasaki H, Le Beau MM Okuno Y, Akashi K, Fiering S, Tenen DG: Acute myeloid leukemia induced by graded reduction of a lineage-specific transcription factor, PU.1. Nat Genet 36: 624-630, 2004.
41. Takahashi S: PU.1, a versatile transcription factor and a suppressor of myeloid leukemia. In: Myeloid leukemia - basic mechanisms of leukemogenesis. Steffen Koschmieder (ed). InTech Europe, Rijeka, Croatia, pp239-262, 2011.

42. Gavert N and Ben-Ze'ev A: beta-Catenin signaling in biological control and cancer. J Cell Biochem 102: 820-828, 2007.

43. Milella M, Kornblau SM, Estrov Z, Carter BZ, Lapillonne H, Harris D, Konopleva M, Zhao S, Estey E and Andreeff M: Therapeutic targeting of the MEK/MAPK signal transduction module in acute myeloid leukemia. J Clin Invest 108: 851-859, 2001.

44. Platanias LC: Map kinase signaling pathways and hematologic malignancies. Blood 101: 4667-4679, 2003.

45. Martelli AM, Nyåkern M, Tabellini G, Bortul R, Tazzari PL, Evangelisti C and Cocco L: Phosphoinositide 3-kinase/Akt signaling pathway and its therapeutical implications for human acute myeloid leukemia. Leukemia 20: 911-928, 2006. 